\title{
Plant-Parasitic Algae (Chlorophyta: Trentepohliales) in American Samoa ${ }^{1}$
}

\author{
Fred E. Brooks ${ }^{2}$
}

\begin{abstract}
A survey conducted between June 2000 and May 2002 on the island of Tutuila, American Samoa, recorded filamentous green algae of the order Trentepohliales (Chlorophyta) and their plant hosts. Putative pathogenicity of the parasitic genus Cephaleuros and its lichenized state, Strigula, was also investigated. Three genera and nine species were identified: Cephaleuros (five spp.), Phycopeltis (two spp.), and Stomatochroon (two spp.). A widely distributed species of Trentepoblia was not classified. These algae occurred on 146 plant species and cultivars in 101 genera and 48 families; $90 \%$ of the hosts were dicotyledonous plants. Cephaleuros spp. have aroused worldwide curiosity, confusion, and concern for over a century. Their hyphaelike filaments, sporangiophores, and associated plant damage have led unsuspecting plant pathologists to misidentify them as fungi, and some phycologists question their parasitic ability. Of the five species of Cephaleuros identified, $C$. virescens was the most prevalent, followed by $C$. parasiticus. Leaf tissue beneath thalli of Cephaleuros spp. on 124 different hosts was dissected with a scalpel and depth of necrosis evaluated using a fourpoint scale. No injury was observed beneath thalli on $6 \%$ of the hosts, but fullthickness necrosis occurred on leaves of $43 \%$ of hosts. Tissue damage beneath nonlichenized Cephaleuros thalli was equal to or greater than damage beneath lichenized thalli (Strigula elegans). In spite of moderate to severe leaf necrosis caused by Cephaleuros spp., damage was usually confined to older leaves near the base of plants. Unhealthy, crowded, poorly maintained plants tended to have the highest percentage of leaf surface area affected by Trentepohliales. Parasitic algae currently are not a problem in American Samoa because few crops are affected and premature leaf abscission or stem dieback rarely occur.
\end{abstract}

Previous reports of plant-parasitic algae in American Samoa were limited to an unidentified species of Cephaleuros Kunze in Fries, 1827, on mango (Mangifera indica L.), guava (Psidium guajava L.), and avocado (Persea americana Mill.) (McKenzie 1996). Cephaleuros is a member of the Trentepohliales, a unique order of filamentous green algae

${ }^{1}$ Funded by the U.S. Department of Agriculture, Cooperative State Research, Education and Extension Service (USDA CSREES, Project SAM-020). Manuscript accepted 1 August 2003.

2 Plant Pathologist, American Samoa Community College Land Grant Program, P.O. Box 5319, Pago Pago, American Samoa 96799 (phone: 684-699-1394; fax: 684-699-5011; e-mail: fredbrooks@hotmail.com).

Pacific Science (2004), vol. 58, no. 3:419-428

(C) 2004 by University of Hawai'i Press

All rights reserved
(Chlorophyta) that are aerial rather than aquatic, brightly colored by orange carotenoid pigments, and uncommon in appearances and lifestyles. A study of this order was initiated in 2000 based on a grower's anxiety over orange, downy growths covering mango and guava leaves. It was also a response to previous authors who hoped to stimulate continued work on these interesting organisms (Joubert and Rijkenberg 1971) and to document existing species of Cephaleuros in the Tropics before their hosts and habitats were destroyed by population growth (Chapman and Good 1983). The goal of this project was to increase our knowledge of algae in the Trentepohliales still existing in American Samoa.

The Trentepohliales currently comprises six genera (Thompson and Wujek 1997). Cephaleuros grows beneath the host's cuticle 
and is considered an obligate epiphyte and occasional parasite by some (Thompson and Wujek 1997) and a plant pathogen by others (Cunningham 1879, Marlatt and Alfieri 1981, Holcomb 1986, Holcomb et al. 1998). Stomatochroon Palm, 1934, lives in the substomatal chambers of its host and was described as an "obligate endophyte (parasite)" by Chapman and Good (1983) and a commensal organism by Timpano and Pearlmutter (1983). Phycopeltis Millardet, 1870, and Physolinum Printz, 1921, are supracuticular epiphytes but may be found on other surfaces under very humid or moist conditions (Thompson and Wujek 1992, Davis and Rands 1993, Rindi and Guiry 2002). The free-living algae Trentepoblia Martius, 1817, and Printzina Thompson \& Wujek, 1992, occur widely on living and nonliving substrates (Chapman 1984, Rindi and Guiry 2002, Thompson and Wujek 1992).

Few plant pathologists have the opportunity to identify plant-pathogenic Trentepohliales as causal agents of disease for several reasons. First, these algae are found mainly in tropical and subtropical climates (Chapman and Good 1983, Thompson and Wujek 1992). Second, though they have a broad host range, their damage is often minimal and the presence of a few small thalli on leaves or stems may go unnoticed (Joubert and Rijkenberg 1971, Holcomb 1986). Finally, algae in this order are sometimes mistaken for fungi due to their filamentous nature and formation of setae, sporangiophores, and zoospores (Cunningham 1879, Singh 1962, Wellman 1965, Chapman 1984, Holcomb and Henk 1984, Reynolds and Dunn 1984). Misidentification is enhanced when fungi invade these algae, forming lichens such as Strigula and Raciborskiella (Santesson 1952, Joubert and Rijkenberg 1971, Chapman and Good 1983, Thompson and Wujek 1997).

Cepbaleuros is the genus commonly linked to plant damage (Joubert and Rijkenberg 1971, Marlatt and Alfieri 1981). Four of the 13 most damaging species grow intercellularly: C. biolopbus Thompson \& Wujek, C. minimus Karsten, C. parasiticus Karsten, and $C$. pilosa Thompson \& Wujek (Thompson and Wujek 1997). The other nine spe- cies, including $C$. virescens, grow beneath the plant's cuticle but above the epidermis and may cause little or no damage to the host. Stomatochroon can cause incidental watersoaking of tissues but is not usually considered a plant parasite.

Cephaleuros virescens is the most frequently reported algal pathogen of higher plants worldwide and has the broadest host range (Joubert and Rijkenberg 1971, Marlatt and Alfieri 1981, Chapman and Good 1983, Holcomb 1986, Thompson and Wujek 1997). It usually occurs on the upper leaf surfaces of perennial dicotyledonous plants, but its thalli occasionally are found on lower leaf surfaces and on monocots (Joubert and Rijkenberg 1971, Chapman and Good 1983). The roughly circular thalli appear velvety due to setae (sterile hairs) and sporangiophores erupting through the host cuticle. The hematochrome pigments astaxanthin and $\beta$ carotene (Thompson and Wujek 1997, Lopez-Bautista et al. 2002) color the Trentepohliales yellow green to dark reddish orange, reportedly due to changes in light, temperature, and available nutrients (Joubert et al. 1975, Lorenz 1999).

The nonintercellular, subcuticular species of Cephaleuros may not induce an obvious response on some hosts (Chapman 1984, Thompson and Wujek 1997). On other hosts, however, cell death occurs beneath the algal thallus (Thomas 1913, Joubert and Rijkenberg 1971, Chapman and Good 1983, Holcomb 1986). There may be tissue hyperplasia, with or without the formation of suberin, either below or at the margins of lesions (Joubert and Rijkenberg 1971, Thompson and Wujek 1997). Stem infections have been implicated in twig death and branch dieback (Ruehle 1936, Knoor 1964, Chapman and Good 1983, Holcomb 1986, Holcomb et al. 1998) and algal spots on guava, avocado, and citrus fruits may reduce their marketability (Winston 1938, Ruehle 1941, Joubert and Rijkenberg 1971, Chapman and Good 1983). Reports have described Cephaleuros spp. as causal agents of disease for over a century (Cunningham 1879, Ruehle 1936, Winston 1938, Crandall and Davis 1944). Steps to confirm its role as a plant pathogen (Koch's 
postulates), however, have not been completed. This is probably due to the difficulty in producing zoospores for reinoculation on artificial media (Chapman and Good 1983, Holcomb et al. 1998).

The objectives of this study were to identify existing species of Trentepohliales in American Samoa and record their host range. The emphasis of this report, however, is on Cephaleuros spp. and their reputed role as plant pathogens.

\section{MATERIALS AND METHODS}

Specimens were collected between June 2000 and May 2002 from a wide range of plant species on Tutuila, main island of the U.S. Territory of American Samoa. Tutuila is located at approximately $14^{\circ} 18^{\prime} \mathrm{S}$ latitude and $170^{\circ} 41^{\prime} \mathrm{W}$ longitude, has a mean annual temperature of $26.4^{\circ} \mathrm{C}$, and annual rainfall from $2,500 \mathrm{~mm}$ at lower elevations to over $6,000 \mathrm{~mm}$ on Matafao Peak $(660 \mathrm{~m})$. Genera of the Trentepohliales sometimes can be identified in the field with a hand lens, but all specimens were taken to the laboratory for species determination by stereo- and light microscopy. Several factors make species identification difficult. The historical use of different morphological characters to distinguish between species has led to incorrect descriptions (Thompson and Wujek 1997) and a need to revise the order (Joubert and Rijkenberg 1971; see also Lopez-Bautista et al. 2002). Further, variability within and between species is possible due to season and exposure (Thompson and Wujek 1997). Species of Cephaleuros, Phycopeltis, and Stomatocbroon were classified in this study based on recently published keys and descriptions by Thompson and Wujek (1997). These characteristics included morphology and location of thalli and sporangiophores, measurements of central filament cells and their width-to-length ratio, and measurements of gametangia and sporangia. Specimens are deposited in the Land Grant Herbarium, American Samoa Community College, $\mathrm{Ma}$ laeimi. Hosts with only a few algal thalli were accessioned as semipermanent microscope slides and photomicrographs.
Two methods were used to estimate disease severity caused by Cephaleuros spp. First, the most seriously affected host leaves were assessed by estimating the percentage of their upper leaf surfaces covered with algae: light $(<5 \%)$, moderate $(6-25 \%)$, or heavy $(>25 \%)$. Disease severity was also measured for mature thalli from a nonrandom sample of hosts using a four-point necrosis index: (0) no necrosis; (1) superficial necrosis of the cell layer beneath the algal thallus, with or without tissue hyperplasia; (2) necrosis of $>1$ cell layer but not full leaf thickness, with or without tissue hyperplasia, erosion, or suberin formation; and (3) necrosis from upper to lower leaf surface, including "shot-hole" symptoms. Damage was assessed under a stereoscope by dissecting fresh and dried lesions with a scalpel.

Lichens with mature fruiting bodies and a species of Cephaleuros as the algal partner were recorded and sent to a lichenologist (C. Smith, University of Hawai'i) for identification. Tissue damage beneath lichen thalli was assessed with the necrosis index and compared with damage by nonlichenized thalli on the same host.

\section{RESULTS}

Cephaleuros, Stomatochroon, Pbycopeltis, and Trentepoblia were collected on the island of Tutuila during this study. The two remaining genera of the Trentepohliales, Printzina and Physolinum, were not found. Algal species identified and the number of plant hosts affected by each (in parentheses) were as follows: Cephaleuros expansa Thompson \& Wujek (7), C. karstenii Schmidle (7), C. minimus Karsten (4), C. parasiticus Karsten (19), C. virescens Kunze in Fries (115), Pbycopeltis epiphyton Millardet (43), P. irregularis (Schmidle) Wille (1), Stomatochroon coalitum Thompson \& Wujek (1), and S. consociatum Thompson \& Wujek (4). Specimens collected and not identified to species level included Cephaleuros (16), Phycopeltis (4), and Trentepoblia (5). Four hosts of $C$. virescens remain unidentified.

There were similarities and differences between the five Cepbaleuros spp. that aided in their classification. Thalli of $C$. expansa, $C$. 

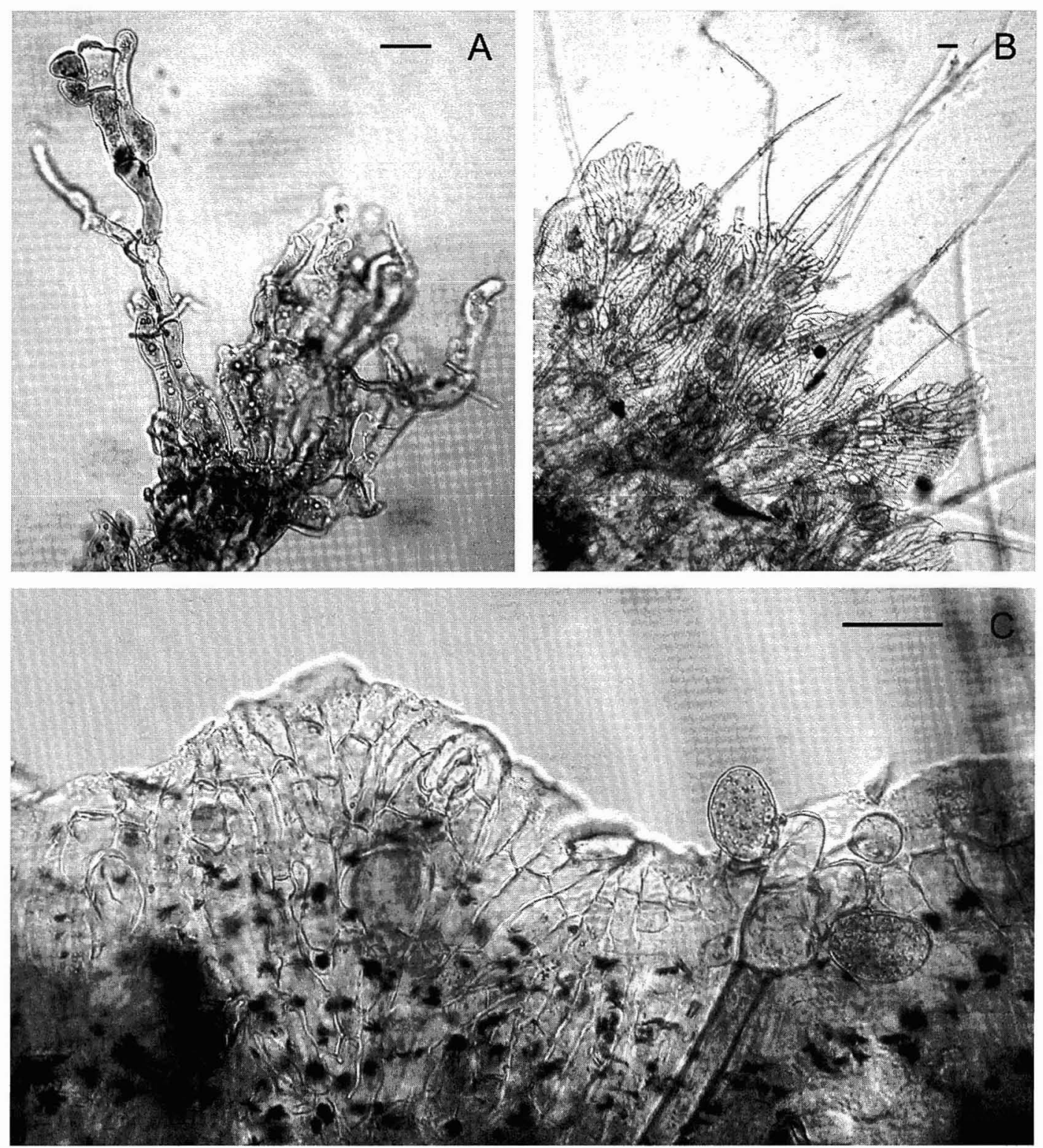

Figure 1. Subcuticular species of Cephaleuros removed from the upper leaf surface of hosts. $A$, Filaments of $C$. expansa fusing to form a false ramulus (branch). $B$, Irregularly lobed thallus (body) of $C$. karstenii with multicellular, sterile hairs. $C$, Entire, closed-ramulate thallus of $C$. virescens (note sporangiophore [right] with head cell and two sporangiatelaterals). Scale bars $=25 \mu \mathrm{m}$.

karstenii, and $C$. virescens grew beneath the host cuticle and were more or less circular. The thallus of $C$. expansa, however, was composed of radiating filaments that occasionally crossed each other, or became laterally fused, forming narrow, false ramuli (Figure $1 A$ ).
Thalli of $C$. karstenii and $C$. virescens were either open- or closed-ramulate (Figure $1 B, C$ ). Ramuli of $C$. karstenii were four to six filaments wide and fan-shaped, and ramuli of $C$. virescens were one to two filaments wide and usually parallel. The width/length ratio 

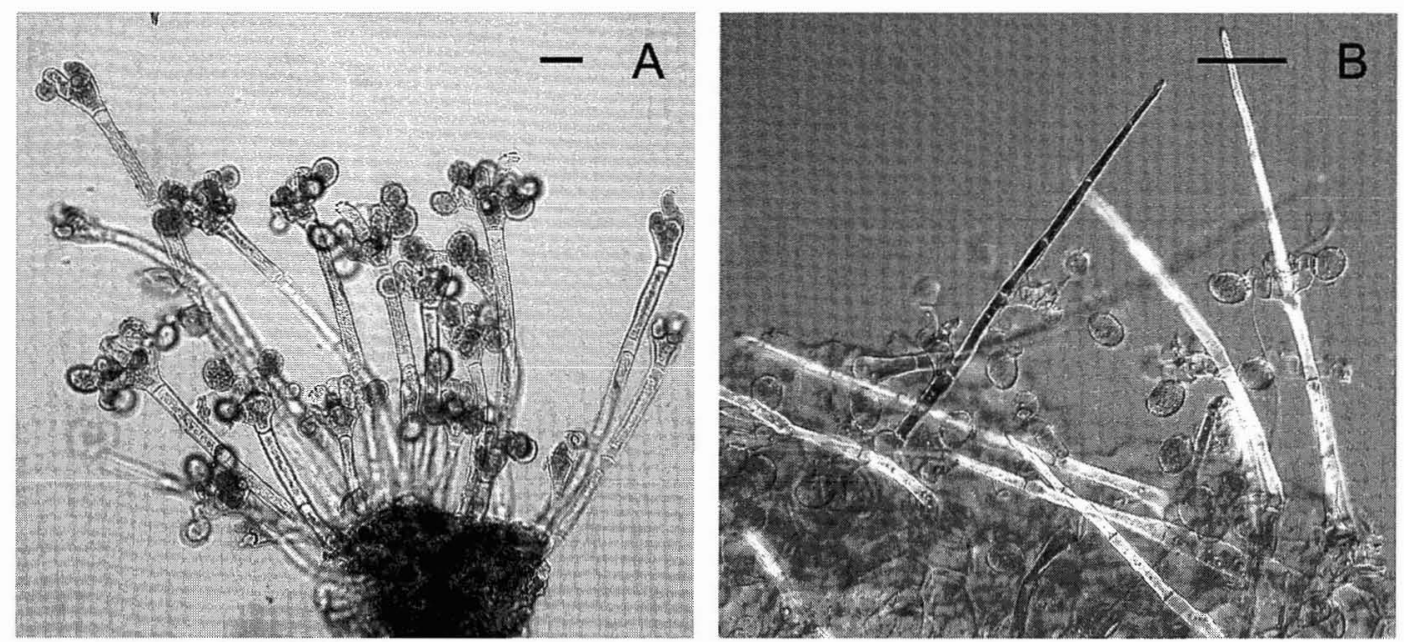

FIGURE 2. Sporangiophores of two intercellular species of Cephaleuros, with attached host tissue, excised from lower leaf surfaces. $A$, Sporangiophores of $C$. parasiticus with terminal whorls of sporangiate-laterals. $B$, Sporangiophores of C. minimus with sporangiate-laterals in twos and threes along one side, and ending in sterile, tapered cells. Scale bars $=25 \mu \mathrm{m}$.

of central filament cells was $1: 4$ for $C$. karstenii and 1:2 for $C$. virescens.

Cephaleuros parasiticus and C. minimus formed scant, filamentous thalli beneath the cuticle on upper leaf surfaces, grew intercellularly, and produced sporangiophores through lower leaf surfaces. Sporangiophores of $C$. parasiticus were typical for the genus, composed of a terminal head cell with radiating sporangiate-laterals (crooked suffultory cells and attached zoosporangia) (Figure $2 A$ ). Conversely, sporangiophores of $C$. minimus were unique, with head cells and sporangiatelaterals along one side and ending in two to three tapered, sterile, apical cells (Figure 2B).

Trentepohliales were collected from 146 plant species and cultivars in 101 genera and 48 families (Table 1). Ninety percent of the hosts (129) were dicotyledonous species. Most algae grew on leaves but were occasionally found on stems and fruit. Sapotaceae was the most commonly affected family, with 14 host species and cultivars.

Percentage of leaf surface area covered by Cephaleuros spp. varied by algal and plant host species: $66 \%(109 / 165)$ of infections were light, $25 \%(42 / 165)$ were moderate, and $9 \%(14 / 165)$ were heavy (Table 2$)$. Because of mixed infections (e.g., $C$. virescens and $C$. parasiticus on the same plant), the number assessed is greater than the total number of plant species collected. Of the infections associated with $C$. virescens $29 \%$ (33/112) were moderate and $9 \%(10 / 112)$ were heavy. Only nine of the 145 hosts examined had moderate to heavy leaf area covered by the other Trentepohliales, Phycopeltis, Stomatochroon, and Trentepoblia.

Of 126 algal infections assessed with the necrosis index, no visible tissue death or discoloration was caused by Cephaleuros spp. on $6 \%(8 / 126)$ of the hosts, $39 \%$ (48/126) scored $1,12 \%(15 / 126)$ scored 2 , and $43 \%(54 / 126)$ scored 3 (Table 3 ). The number of algal infections assessed with the necrosis index was less than either the number of hosts collected or estimates for percentage leaf surface area covered, because the necrosis index was initiated near the end of the study and some host specimens were not available for sectioning.

Lichenized thalli of Cephaleuros spp. with mature perithecia were found on 33 of 124 hosts and identified as Strigula elegans (C. Smith, pers. comm.). Tissue damage caused by $S$. elegans was less severe than $(16 / 33)$ or the same as (17/33) damage caused by the alga alone. Recording lichenized forms of 
TABLE 1

A List of Plant Hosts ${ }^{a}$ of Cephaleuros, Phycopeltis, and Stomatochroon on Tutuila, American Samoa

Acanthaceae

Aphelandra sinclairiana Nees; Cvir

Odontonema tubiforme (Bertoloni) Kuntze; Cvir Pseuderanthemum carrutbersii var. reticulatum (Seem.) Guillaumin; Cvir

Agavaceae

Cordyline terminalis (L.) Chevallier; Csp

Pleomele sp. (Roxburgh) N. E. Brown; Pepi

Amaryllidaceae

Crinum asiaticum L.; Cexp

Anacardiaceae

Anacardium occidentale L.; Cvir ${ }^{+}$

Mangifera indica L.; Cvir, Cpar*, Scon

Annonaceae

Annona muricata L.; Cvir*

A. muricata 'Cuban Fiberless' L.; Cvir ${ }^{*}$

A. muricata 'Dulce Cuban' L.; Cvir

A. squamosa 'Seedless' L.; Cvir

A. squamosa $\times$ A. cherimoya 'Pink Mammoth' L.; Cvir*, Cpar*

Rollinia deliciosa Saff.; Cvir ${ }^{+}$, Pepi, Scoa

Apocynaceae

Allamanda sp. L.; Cexp

A. catbartica L.; Cvir

Carissa grandiflora (E. Meyer) A. L. P. P. de Candolle; Cvir

Araceae

Anthurium sp. Linden ex Andre; Cvir, Pepi

Epipremnum pinnatum (L.) Engler; Cexp, Cvir*

Araliaceae

Polyscias fruticosa (L.) Harms; Cvir*

P. scutellaria (N. L. Burman) Fosberg; Cvir

Arecaceae

Cbrysalidocarpus lutescens $\mathrm{H}$. Wendl.; Pepi

Metroxylon vitiense (H. Wendl.) Hook.f.; Cvir, Psp

Pritchardia pacifica Seem. \& H. Wendl.; Cvir, Pepi

Veitchia merrillii (Becc.) H. E. Moore; Cpar*, Pepi

Asclepiadaceae

Hoya australis R. Brown; Cvir, Pepi

Begoniaceae Begonia sp.; Ckar

Bignoniaceae Tabebuia beteropbylla (DC.) Britton; Cvir

Bixaceae

Bixa orellana L.; Cpar ${ }^{\star}$, Cvir

Bombacaceae

Cieba pentandra (L.) Gaertn.; Cvir

Durio zibethinus Moon; Cvir ${ }^{*}, \mathrm{Pepi}^{+}$

Pachira aquatica Aubl.; Cvir

Burseraceae

Canarium ovatum Engl.; Cvir

Clusiaceae

Calophyllum inophyllum L.; $\mathrm{Cvir}^{+}$

C. neo-ebudicum Guillaumin; Pepi

Combretaceae

Terminalia samoensis Rechinger; Cvir ${ }^{*}$

Convolvulaceae

Operculina turpetbum (L.) Silva Manso; Csp
Cupressaceae

Cupressus sp. L.; Ckar

Ebenaceae

Diospyros samoensis A. Gray; Pepi

Euphorbiaceae

Aleurites moluccana (L.) Willd.; Cvir*

Codiaeum variegatum (L.) A. H. L. Jussieu; Cvir*, Pepi

C. v. pictum 'Acubifolium' (L.) A. H. L. Jussieu; Cvir

C. v. pictum 'Majesticum' (L.) A. H. L. Jussieu; Cvir*, Pepi

C. v. pictum 'Stewartii' (L.) A. H. L. Jussieu; Csp

Euphorbia neriifolia L.; Cvir

Flueggea flexuosa Muell. Arg.; Cvir, Pepi

fatropha integerrima Jacquin; Cvir, Pepi

Pedilanthus tithymaloides L.; Cvir*, Pepi

Fabaceae

Acacia sp.; Cvir, Csp, Pepi, Scon

A. mangium Willd.; Csp

Calliandra surinamensis Bentham.; Cvir

Cassia javanica L.; Cvir

Intsia bijuga (Colebr.) Kuntze; Ckar, $\mathrm{Cvir}^{+}$, Pepi

Pterocarpus indicus Willd.; Csp

Sophora tomentosa L.; Cvir

Heliconiaceae

Heliconia $\times$ 'Golden Torch' L.; Cpar

Lauraceae

Persea americana Miller; Cvir

Leeaceae

Leea guineensis G. Don; Cexp*, Cpar*, Cvir*, Csp*

Loganiaceae

Fagraea berteroana A. Gray ex Benth.; Cvir

Lythraceae

Cuphea melvilla Lindl.; Cpar*, $\mathrm{Csp}^{+}$, Scon

Lagerstroemia speciosa (L.) Pers.; Cmin*, Cpar ${ }^{*}, \mathrm{Cvir}^{*+}$, Csp, Scon

Magnoliaceae

Michelia champaca L.; Ckar, Pepi

Malvaceae

Hibiscus rosa-sinensis L.; Cmin, Cvir, Csp, Pepi

H. tiliaceus L.; Cvir

H. tiliaceus cv. L.; Cvir

Marantaceae

Maranta arundinacea 'Variegata' L.; Cpar*, Cvir, Pepi

Meliaceae

Lansium domesticum Correa; Cvir

Melia azedarach Blanco; Cvir, Psp

Swietenia macrophylla King; Ckar, Pepi

Moraceae

Artocarpus altilis (J. D. Hooker) Schlechter; Cvir

Ficus benghalensis L.; Cvir

$F$. benjamina L.; Cvir ${ }^{*}$

$F$. elastica Roxb. ex Hornem.; Cvir

$F$. prolixa Forst.f.; Cvir, Pepi

$F$. tinctoria Forst.f.; Cvir

Myrtaceae

Eugenia uniflora L.; Cvir*

Psidium guajava L.; Cvir*, Pepi

P. guajava 'Waikea' L.; Cpar ${ }^{\star}$, Cvir ${ }^{+}$ 
TABLE 1 (continued)

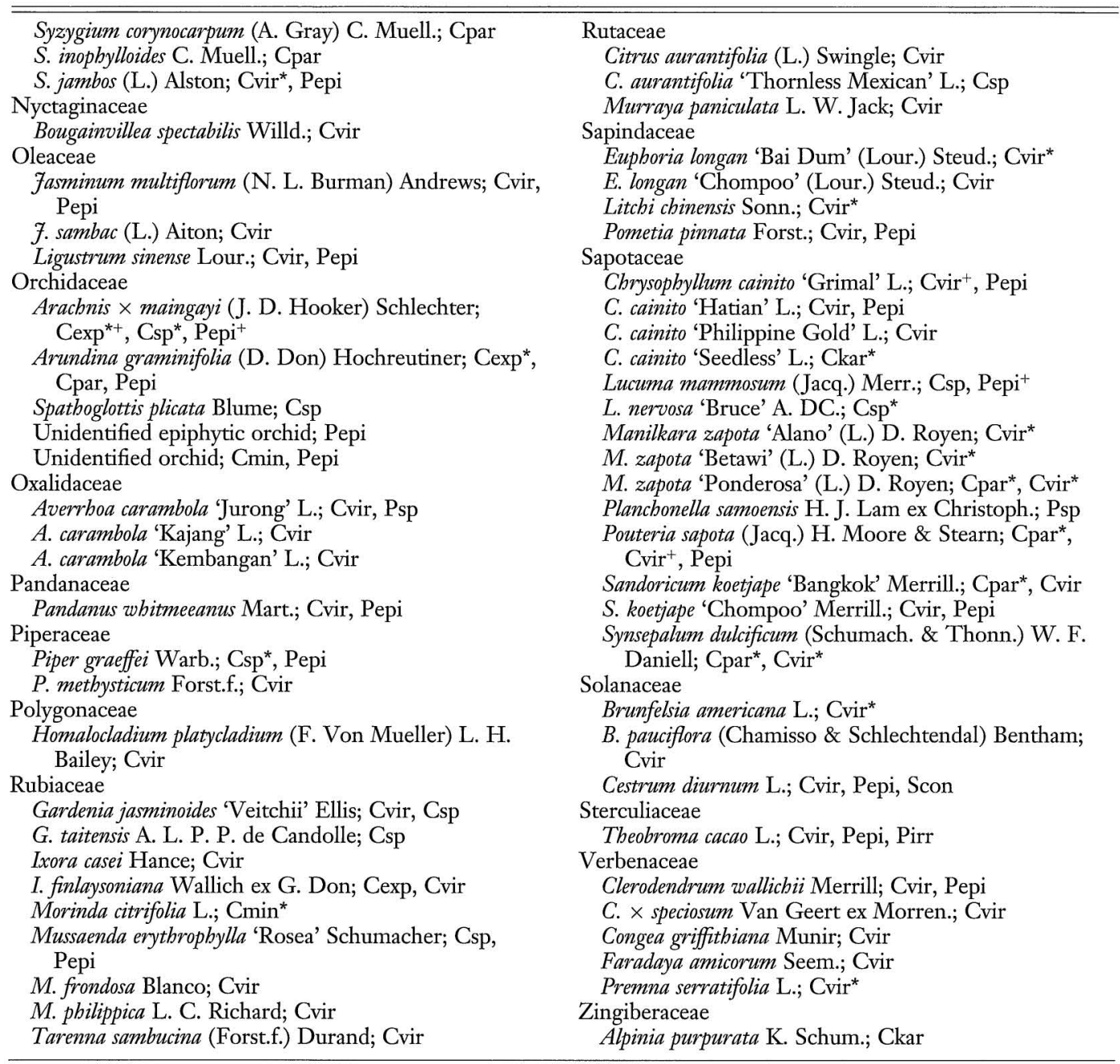

Note: The name of each host is followed by its authority, algal species (Csp, Cephaleuros sp.; Cexp, C. expansa; Ckar, C. karstenii; Cmin, C. minimus; Cpar, C. parasiticus; Cvir, C. virescens; Psp, Phycopeltis sp.; Pepi, P. epiphyton; Pirr, P. irregularis; Scoa, Stomatochroon coalitum; Scon, $S$. consociatum), and severity of disease $\left(+,>25 \%\right.$ of leaf area covered by the alga; ${ }^{*}$, full-thickness leaf necrosis) caused by Cephaleuros spp.

"Table does not include unidentified hosts, except two orchid spp., nor hosts of Trentepoblia.

the nonparasitic species Pbycopeltis and Trentepoblia was outside the objectives of this study.

\section{DISCUSSION}

Algae of the order Trentepohliales, especially $C$. virescens and $P$. epiphyton, have a broad plant host range in American Samoa (Table 1). Most of the hosts are perennial dicots, agreeing with reports from other tropical and subtropical locations (Marlatt and Alfieri 1981, Holcomb 1986, Thompson and Wujek 1997). However, the number of algal species identified in American Samoa, especially the five Cephaleuros spp., was higher than re- 
TABLE 2

Percentage Upper Süface of Plant Host Leaves Covered by Cephaleuros spp., Tutuila, American Samoa

\begin{tabular}{lccc}
\hline \hline & \multicolumn{3}{c}{$\begin{array}{c}\text { No. Hosts Affected at Each } \\
\text { Level of Leaf Area Covered }\end{array}$} \\
\cline { 2 - 4 } Alga & $<5 \%$ & $6-25 \%$ & $>25 \%$ \\
\hline Cephaleuros expansa & 6 & $-b$ & 1 \\
C. karstenii & 7 & - & - \\
C. minimus & 3 & 1 & - \\
C. parasiticus & 12 & 4 & 3 \\
C. virescens & 69 & 33 & 10 \\
C. sp. & 12 & 4 & - \\
Total & 109 & 42 & 14 \\
\hline
\end{tabular}

a Some host leaf surfaces were infected by more than one species of Cepbaleuros.

${ }^{b}$ No hosts recorded for the algal species at this level.

ported in many areas (Thompson and Wujek 1997). For example, Holcomb (1986) reported 218 plant hosts in Louisiana but only one algal species, $C$. virescens. Marlatt and Alfieri (1981) did not identify the species of Cepbaleuros found on 157 hosts in Florida.

The only plant damage associated with Stomatocbroon spp. during this study was water-soaking caused by a heavy infection

\section{TABLE 3}

Host Leaf Damage Caused by Cephaleuros spp. on Tutuila, American Samoa, as Measured by a Necrosis Index ${ }^{a}$

No. Hosts Affected at Each Level of Necrosis ${ }^{b}$

\begin{tabular}{lcccr}
\cline { 2 - 5 } Alga & 0 & 1 & 2 & 3 \\
\hline Cephaleuros expansa & - & 3 & - & 4 \\
C. karstenii & - & 4 & - & 1 \\
C. minimus & - & 2 & - & 2 \\
C. parasiticus & - & - & - & 14 \\
C. virescens & 8 & 39 & 15 & 30 \\
C. sp. & $\overline{8}$ & $\overline{48}$ & $\overline{15}$ & 55 \\
$\quad$ Total & &
\end{tabular}

${ }^{a}$ Necrosis index: 0 , no necrosis; 1, superficial necrosis of the cell layer beneath the thallus, with or without tissue hyperplasia; 2, necrosis of $>1$ cell layer but not full leaf thickness, with or without tissue hyperplasia, erosion, or suberization; 3, full-thickness necrosis from upper to lower leaf surface, or "shothole" symptoms.

"Some hosts were infected by more than one species of Cepbaleuros.

${ }^{c}$ No hosts recorded for the algal species at this level. of $S$. consociatum on the underside of leaves of the firecracker plant (Cuphea sp.). Watersoaking and browning of tissue may occur when sporangiophores of the alga block stomates and inhibit gas exchange (Chapman and Good 1983, Timpano and Pearlmutter 1983). This incidental damage might not qualify Stomatochroon as a plant pathogen, but it appears to be more than a space opportunist. The autotrophic $S$. consociatum, for example, was grown on an inorganic salts medium by Timpano and Pearlmutter (1983), but all stages of its life cycle could not be induced. Those researchers suggested that the alga receives necessary chemicals from its host but neither benefits nor harms the plant (commensalism).

McKenzie (1996) was probably correct in suggesting that species of Trentepohliales collected in American Samoa from mango, guava, and avocado were Cepbaleuros virescens. This was the most commonly identified species in the current study and the most abundant alga of the Trentepohliales found on these three trees species. Cepbaleuros parasiticus, Pbycopeltis epipbyton, and Stomatochroon consociatum were also isolated from these hosts (Table 1).

Thalli of $C$. virescens usually grow on upper leaf surfaces but were also common on the undersides of heavily infected leaves. This distribution was especially apparent when leaves were either twisted to expose their lower surfaces, had infections along their margins, or were split, with thalli surrounding the break on the upper leaf surface. These conditions favor infection of the lower leaf surface by zoospores swimming in a film of water connecting the two leaf surfaces (Chapman and Good 1983). In a cumulative study in Louisiana from 1972 to the mid1980s, Holcomb (1986) reported C. virescens only on upper leaf surfaces of all hosts except Camellia japonica, which had thalli on both surfaces.

Stem infections associated with $C$. virescens were rare in the current study, appearing only on kava (Piper metbysticum) and the zigzag plant (Pedilantbus titbymaloides). In the Louisiana study (Holcomb 1986), however, 17 stem infections were reported, and recently workers described cane infections on culti- 
vated blackberry in Arkansas and Louisiana (Holcomb et al. 1998).

Thompson and Wujek (1997) considered C. virescens a "relatively innocuous" species, causing obvious necrosis on only a few plant hosts. They disagreed in general with published reports identifying $C$. virescens as a primary agent of disease. Thompson and Wujek attributed the errors in those reports either: (1) to misidentification of the alga, (2) to the alga growing opportunistically in lesions made by other organisms or environmental conditions, (3) or to the fungal component of the lichenized alga being the actual cause of the damage. Results of the American Samoa study differ from those of Thompson and Wujek. Thalli of $C$. virescens usually occurred in the absence of signs or symptoms of other biotic agents or visible damage caused by the environment. As algae matured the diameter of tissue necrosis mirrored thallus growth. This relationship between the presence of an algal thallus and host necrosis in the absence of other lesion-forming organisms suggests that $C$. virescens is a primary pathogen, able to cause disease. Until plants can be inoculated with zoospores of $C$. virescens and the same symptoms produced (Koch's postulates), however, its pathogenicity remains tentative (Agrios 1997).

Damage caused by $C$. virescens on 33 plant hosts in American Samoa was greater than or equal to damage caused to the same hosts by its lichenized form, Strigula elegans. This observation argues against Thompson and Wujek's contention (1997) that the fungal partner of the lichen is the cause of disease, but agrees with Chapman and Good's finding (1983) that necrosis beneath a lichenized Cephaleuros thallus is produced by the alga before lichenization. Ultrastructural studies have shown that the fungus parasitizes its algal host and not the plant (Chapman 1976). If a plant-pathogenic fungus were to associate with $C$. virescens damage could occur (Chapman and Good 1983), but that was not the case with $S$. elegans in this study.

Host tissue necrosis was present beneath Cepbaleuros thalli on over $90 \%$ of the 126 hosts indexed and was moderate to severe on $55 \%$ (Table 3). Comparatively, Holcomb (1986) described moderately severe to severe host responses, and leaf spotting, on only $8 \%$ of 218 hosts. The terms moderately severe and severe were not defined in the Louisiana report, however, and may not be comparable with the disease severity scales used in the current study.

Tropical fruit trees in the Sapotaceae were more heavily affected by Trentepohliales than other plant families (Table 1). They had the broadest host range, a moderate to heavy percentage leaf area covered by the algae, and full-thickness necrosis on many leaves. Most specimens, however, were collected from a crowded, poorly maintained fruit orchard where heavy shading, lack of nutrients, and high inoculum levels may have increased host susceptibility. Control measures under these conditions would include plant spacing and thinning to improve aeration and light, optimum fertilization, orchard sanitation, and selecting cultivars for the local environment.

Algae in the order Trentepohliales remain a mystery to most American Samoans, because plant-parasitic Cephaleuros species do not affect important subsistence crops, such as banana and taro. Occasional blemishes caused by algae on other types of produce and on landscape plants are tolerated. Because control measures are not usually applied and most Trentepohliales have a broad host range, their existence in American Samoa is relatively secure in spite of habitat destruction due to population pressure and natural disaster.

\section{ACKNOWLEDGMENTS}

My special thanks to D. Wujek for his continued support, R. Chapman and his laboratory for their suggestions and encouragement, and O. C. Steele for assisting in plant identifications.

\section{Literature Cited}

Agrios, G. N. 1997. Plant pathology. 4th ed. Academic Press, New York.

Chapman, R. L. 1976. Ultrastructure of Cepbaleuros virescens (Chroolepidaceae; Chlorophyta). I. Scanning electron microscopy of zoosporangia. Am. J. Bot. 63:1060-1070. 
1984. An assessment of the current state of our knowledge of the Trentepohliaceae. Pages 233-350 in D. E. G. Irvine and D. M. John, eds. Systematics of the green algae. Syst. Assoc. Spec. Vol. 27.

Chapman, R. L., and B. H. Good. 1983. Subaerial symbiotic green algae: Interactions with vascular plant hosts. Pages 173-204 in L. J. Goff, ed. Algal symbiosis: A continuum of interaction strategies. Cambridge University Press, Cambridge.

Crandall, B. S., and W. C. Davis. 1944. Cepbaleuros virescens on chinchona in Central and South America. Plant Dis. Rep. 28:926.

Cunningham, D. D. 1879. On Mycoidea parasitica, a new genus of parasitic algae and the part which it plays in the formation of certain lichens. Linn. Soc. Trans. 1:301318.

Davis, J. S., and D. G. Rands. 1993. Observations on lichenized and free-living $P b y$ solinum (Chlorophyta, Trentepohliaceae). J. Phycol. 29:819-825.

Holcomb, G. E. 1986. Hosts of the parasitic alga Cephaleuros virescens in Louisiana and new host records for the Continental United States. Plant Dis. 70:1080-1083.

Holcomb, G. E., and M. C. Henk. 1984. Spot of Magnolia grandiflora. Phytopathology 74:822.

Holcomb, G. E., S. R. Vann, and J. B. Buckley. 1998. First report of Cephaleuros virescens in Arkansas and its occurrence on cultivated blackberry in Arkansas and Louisiana. Plant Dis. 82:263.

Joubert, J. J., and F. H. J. Rijkenberg. 1971. Parasitic green algae. Annu. Rev. Phytopathol. 9:45-64.

Joubert, J. J., F. H. J. Rijkenberg, and P. L. Steyn. 1975. Studies on the physiology of a parasitic green alga, Cephaleuros sp. Phytopathol. Z. 84:147-152.

Knorr, L. C. 1964. A suggestion that the Lee tangerine may be hypersensitive to Cephaleuros virescens. Plant Dis. Rep. 48:478479.

Lopez-Bautista, J. M., D. A. Waters, and R. L. Chapman. 2002. The Trentepohliales revisited. Constancea 83 (1). http://ucjeps .berkeley.edu/constancea/83/lopez_etal/ trentepohliales.html. Accessed 16 December 2002.

Lorenz, T. 1999. A technical review of Haematococcus. http://www.cyanotech.com/ pdfs/axbul60.pdf. Accessed 27 December 2002.

Marlatt, R. B., and S. A. Alfieri Jr. 1981. Hosts of a parasitic alga, Cephaleuros Kunze, in Florida. Plant Dis. 65:520-522.

McKenzie, E. H. C. 1996. Fungi, bacteria and pathogenic algae on plants in American Samoa. Technical Paper 206. South Pacific Commission, Noumea, New Caledonia.

Reynolds, D. R., and P. H. Dunn. 1984. A fungus-like alga. Mycologia 76:719-721.

Rindi, F., and M. D. Guiry. 2002. Diversity, life history, and ecology of Trentepoblia and Printzina (Trentepohliales, Chlorophyta) in urban habitats in Western Ireland. J. Phycol. 38:39-54.

Ruehle, G. D. 1936. An epiphytotic of algal spot in South Florida. Plant Dis. Rep. 20:221-222.

-1941. Algal leaf and fruit spot of guava. Phytopathology 31:95-96.

Santesson, R. 1952. Foliicolous lichens I: A revision of the taxonomy of the obligately foliicolous, lichenized fungi. Symb. Bot. Ups. 12:1-590.

Singh, R. N. 1962. A problematic filamentous saprophytic alga. Am. J. Bot. 49:188-191.

Thomas, N. 1913. Notes on Cephaleuros. Ann. Bot. (Lond.) 28:781-793.

Thompson, R. H., and D. E. Wujek. 1992. Printzina gen. nov. (Trentepohliaceae), including a description of a new species. J. Phycol. 28:232-237.

. 1997. Trentepohliales: Cepbaleuros, Pbycopeltis, and Stomatochroon: Morphology, taxonomy, and ecology. Science Publishers, Enfield, New Hampshire.

Timpano, P., and N. L. Pearlmutter. 1983. Algal invasion of angiosperm mesophyll. SEM Inc., AMF O'Hare, Chicago.

Wellman, F. L. 1965. Pathogenicity of Cepbaleuros virescens in the Neotropics. Phytopathology 55:1082.

Winston, J. R. 1938. Algal fruit spot of orange. Phytopathology 28:283-286. 